International Journal of Current Microbiology and Applied Sciences

ISSN: 2319-7706 Volume 6 Number 7 (2017) pp. 255-260

Journal homepage: http://www.ijcmas.com

Original Research Article

https://doi.org/10.20546/ijcmas.2017.607.030

\title{
Efficacy of Nematoctonus robustus along with Organic Amendment for the Management of Rice Root Knot Nematode Meloidogyne graminicola
}

\author{
Dalel Singh*, Sumit Kumar Pandey and R.K. Singh
}

Department of Mycology and Plant Pathology, Institute of agricultural Sciences, Banaras Hindu University, Varanasi - 221005, Uttar Pradesh, India

*Corresponding author

\section{A B S T R A C T}

\begin{tabular}{|c|c|}
\hline $\begin{array}{l}\text { Ke y w or d s } \\
\text { Nematoctonus } \\
\text { robustus, } \\
\text { Meloidogyne } \\
\text { graminicola, Rice, } \\
\text { Vermicompost, } \\
\text { FYM. } \\
\end{array}$ & $\begin{array}{l}\text { The efficacy of Nematoctonus robustus along with neem cake, FYM and Vermi } \\
\text { compost was assessed either singly or in combination as soil application for } \\
\text { management of rice root knot nematode, Meloidogyne graminicola in transplanted } \\
\text { rice variety MTU- } 7029 \text {. Observation were recorded on rice plant growth } \\
\text { parameter as shoot and root length, fresh weight, shoot and root weight, nematode } \\
\text { root galls, eggs masses, females and juveniles. Application of Nematoctonus } \\
\text { robustus } 30 \mathrm{~g} / \mathrm{kg} \text { soil and neem cake } 15 \mathrm{~g} / \mathrm{kg} \text { soil enhanced rice plant growth }\end{array}$ \\
\hline Arti & \\
\hline $\begin{array}{l}\text { Accepted: } \\
\text { 04 June } 2017 \\
\text { Available Online: } \\
\text { 10 July } 2017\end{array}$ & $\begin{array}{l}\text { nematode. Fewest root gall (2.0), population of egg masses ( } 348.7 \text { ), population of } \\
\text { females (3.6) and population of juveniles (1.7) of Meloidogyne graminicola were } \\
\text { recorded in the application of Nematoctonus robustus } 30 \mathrm{~g} / \mathrm{kg} \text { soil + FYM } 50 \mathrm{~g} / \mathrm{kg} \\
\text { soil and Nematoctonus robustus } 30 \mathrm{~g} / \mathrm{kg} \text { soil + Vermicompost } 50 \mathrm{~g} / \mathrm{kg} \text { soil. }\end{array}$ \\
\hline
\end{tabular}

\section{Introduction}

Root knot Nematodes, Meloidogyne spp. have been reported infecting rice crops is found wide but Meloidogyne graminicola is a serious pest of upland rice and nurseries grown on well drained soils. Rice plays an important role in the livelihood of the people of India. Fresh water availability for irrigation is decreasing worldwide because of increasing competition from urban and industrial development, degrading irrigation infrastructure and deteriorating water quality (Molden, 2007). This nematode was recorded during 2009- 10 in Bulandshahr district of Uttar Pradesh, causing an average yield loss of $20-25 \%$ and in some case to the tune of 50-
60\% loss (Pankaj et al., 2010). The disease can assume epidemic proportion causing extensive damage to the crop. The nematode infestation is manifested by root galling, yellowing, stunting and wilting of the plant. The rice root knot nematode, Meloidogyne graminicola completes its life cycle in 15 days at $27-37^{\mathrm{C}}$ (Jaiswal et al., 2010). Meloidogyne graminicola is one of the most predominant pests associated with rice under upland condition (Bridge et al., 1990) and cause substantial yield losses (Protet et al., 1995, Soriano et al., 2000) Biological control of plant parasitic nematodes is regarded as an important component of integrated nematode 
management system and it acts as an alternative to various chemical Pesticides due to their self-sustaining action. The control of plant parasites nematodes is a difficult task, and mainly depends on chemical nematicides for decades and remarkable reduction of nematode population has been achieved (Akhtar and Malik 2000). Although soil nematicides are effective and fast-acting, they are currently being reappraised with respect to the environmental hazards and human health (Wachira et al., 2009). In addition to that they are relatively unaffordable to many small scale farmers.

Hence an eco-friendly and environmentally safe technique is aimed incorporating bioagents in the management of root knot nematode under field conditions. Musabyimana and Saxena (1999) have reported that application of neem cake at 100 g/plant reduced the numbers of Pratylenchus goodeyi and Meloidogyne spp. in banana.

One way to reduce water and labour requirement is to grow dry seeded rice instead of the puddled transplanted rice (Yadav et al., 2010; Jain et al., 2007) have worked out the monetary loss to the extent of 4779.00 million rupees in rice due to Meloidogyne graminicola, Heterodera oryzicola and Aphelenchoides besseyi causing an average yield loss to the tune of $10.54 \%$. However, crop losses to the extent of $60-100 \%$ have also been reported (Dabur and Jain. 2005). Use of organic amendments and bio-control agents are some of the exciting and promising means of management practices which aims at the suppression of nematode population to manageable limits.

\section{Materials and Methods}

The pot experiment was arranged in a green house in completely randomized block design (CRD) to accommodate soil application of rice plant with using mass culture of bio control agent Nematoctonus robustus by mixing in sick soil @ $1 \mathrm{~kg} /$ pots with susceptible varieties of MTU-7029 on the basis of application with different organic substrates like Vermi-compost, Farm Yard Manure (FYM), and Neem cake at the Institute of Agricultural Sciences, Department of Mycology and Plant Pathology, Banaras Hindu University, Varanasi, Uttar Pradesh.

The composite sick soil of each pot was filled in three earthen pots 15 @ $1 \mathrm{~kg}$ per pot and kept in green house at $25-35^{\mathrm{C}}$ temperature and 25 sprouted rice seeds (variety MTU-7029) with mixing different organic substrates as Vermi compost, FYM, Neem cake and Nematoctonus robustus were sown to each pot and irrigated daily after 20 days of sowing the seedling of each pot of all soil samples were uprooted and carefully washed under running tap water and number of root galls, shoot and root length, fresh weight of root and shoot, population of eggs, juveniles and females per seedling was determined.

The treatments were- $\mathrm{T}_{1}$ Vermicompost 10 gram + Sick Soil + MTU-7029, $\mathrm{T}_{2}$ Vermi compost 50 gram + Sick Soil + MTU-7029, $\mathrm{T}_{3}$ FYM 10 gram + Sick Soil + MTU -7029, $\mathrm{T}_{4}$ FYM 50 gram + Sick Soil + MTU-7029, $\mathrm{T}_{5}$ Neem Cake 10 gram + Sick Soil + MTU 7029, $\mathrm{T}_{6}$ Neem Cake 15 gram + Sick Soil + MTU-7029, $\mathrm{T}_{7}$ Nematoctonus robustus 30 gram + Vermicompost 10 gram + Sick Soil + MTU-7029, $\mathrm{T}_{8}$ Nematoctonus robustus 30 gram + Vermicompost 50 gram + Sick Soil + MTU-7029, $\mathrm{T}_{9}$ Nematoctonus robustus 30 gram + FYM 10 gram + Sick Soil + MTU7029, $\mathrm{T}_{10}$ Nematoctonus robustus 30 gram + FYM 50 gram + Sick Soil + MTU-7029, T $_{11}$ Nematoctonus robustus 30 gram + Neem Cake 10 gram + Sick Soil + MTU-7029, T 12 Nematoctonus robustus 30 gram + Neem Cake 15 gram + Sick Soil + MTU-7029, T0 (Control) - Only nematode infected soil (Meloidogyne graminicola) with MTU- 7029. 
Mass culture preparation of Nematoctonus robustus

Sorghum, barley grains and straw of wheat were tested for the growth of nematoctonus robustus in mass culture. Barns and straw were powdered and grains were spitted in warring blender before addition of desired amount of water. Substrates and water were taken as follows: Sorghum grain 20 gram + $35 \mathrm{ml}$ water, wheat straw 5 gram $+40 \mathrm{ml}$ water, Barley grain 20 gram $+35 \mathrm{ml}$ water. Each substrate was taken in to a $250 \mathrm{ml}$ conical flask and moistened with desired amount of water as mentioned above.

The flasks were plugged with cotton and sterilized two times at 15 psi for 20 minutes. A $10 \mathrm{~mm}$ fungal disc was cut from the periphery of the 15 days old culture of isolate a by a sterilized cork borer and inoculation in the centre of a substrate contained in a flask with the help of sterilized inoculation on needle. One fungal disc was inoculated in to each flask five replications were maintained for each treatment. The inoculated flasks were incubated at $25+-1^{\circ} \mathrm{C}$. Visual rating was made to assess the growth of Nematoctonus robustus after 25 days of inoculation.

\section{Results and Discussion}

An investigation was carried out to study the Bio control Potential of root knot nematode Meloidogyne graminicola on rice and its management through organic amendments. Different growth parameter was taken to assess the infestation and bio potentiality of root knot nematode and Nematoctonus robustus respectively.

The experimental results represented in table 1 revealed that the shoot length of rice plant significantly increased in $\mathrm{T}_{12}(29.4 \mathrm{~cm})$ followed $\mathrm{T}_{10}(27.8 \mathrm{~cm}), \mathrm{T}_{8}(24.0 \mathrm{~cm}), \mathrm{T}_{11}$ $(22.7 \mathrm{~cm})$ and $\mathrm{T}_{9}(21.7 \mathrm{~cm})$ as compared with other treatment. Among the treatment $\mathrm{T}_{7}$
(20.2 cm), $\mathrm{T}_{6}(19.6 \mathrm{~cm})$, and $\mathrm{T}_{2}(18.5 \mathrm{~cm})$ were found non-significant from each other significantly increased the shoot length as compared with untreated control $\mathrm{T}_{0}$ $(10.23 \mathrm{~cm})$. The root length of rice as significantly increased in $\mathrm{T}_{12}(14.0 \mathrm{~cm}), \mathrm{T}_{10}$ $(12.8 \mathrm{~cm})$ and $\mathrm{T}_{8}(9.9 \mathrm{~cm})$ as compared with $\mathrm{T}_{9}(7.5 \mathrm{~cm}), \mathrm{T}_{1}(3.1 \mathrm{~cm})$ and $\mathrm{T}_{0}(1.86 \mathrm{~cm})$.

The fresh shoot weight of rice plant was significantly increased in $\mathrm{T}_{12}(2.267 \mathrm{mg}), \mathrm{T}_{10}$ $(1.26 \mathrm{mg})$ and $\mathrm{T}_{8}(0.777 \mathrm{mg})$ as compared with $\mathrm{T}_{0}(0.115 \mathrm{mg})$ and $\mathrm{T}_{1}(0.297 \mathrm{mg})$. Fresh root weight in treatment $\mathrm{T}_{12}(0.448 \mathrm{mg}), \mathrm{T}_{10}$ $(0.356)$ and $\mathrm{T}_{8}(0.276 \mathrm{mg})$ significantly increased from $\mathrm{T}_{0}(0.110 \mathrm{mg}), \mathrm{T}_{1}(0.150 \mathrm{mg})$ and $\mathrm{T}_{3}(0.161 \mathrm{mg})$ respectively.

The number of root galls was significantly increased in T0 (39.0), T1 (17.3), T3 (16.0) and T4 (12.0) as compared with T12 (2.0), T10 (3.0), T8 (8.0) and T11 (8.7). These treatments were significantly different from all the other treatment. Significantly more galls (39.0) were recorded in the control (T0) than all other treatment.

The number of eggs population was significantly increased in $\mathrm{T}_{0}$ (964.0), $\mathrm{T}_{1}$ (761.7) and $\mathrm{T}_{3}$ (742.7) as compared with lowest eggs population $\mathrm{T}_{12}$ (348.7), $\mathrm{T}_{10}$ (422.7) and $\mathrm{T}_{9}$ (650.3). Lowest eggs population was recorded in $\mathrm{T}_{12}$ (348.7) and greatest number of eggs mass population was recorded in the untreated control $\left(\mathrm{T}_{0}\right)$ and mass eggs population observed (964.0) than all other treatment.

The number of females in various treatments showed that significantly maximum number of females $\mathrm{T}_{0}$ (25.1), $\mathrm{T}_{1}$ (21.5) and $\mathrm{T}_{3}$ (17.1) compared with in $\mathrm{T}_{12}$ (3.6), $\mathrm{T}_{10}$ (6.3) and $\mathrm{T}_{8}$ (7.1) respectively. Lowest number of females in $T_{12}$ (3.6) and maximum number of females in untreated control (25.1) were recorded. 
Table.1 Plant growth and nematode population in rice MTU- 7029 with Nematoctonus robustus, Neem cack, FYM, vermicompost at soil application

\begin{tabular}{|c|c|c|c|c|c|c|c|c|}
\hline Treatment & $\begin{array}{c}\text { Shoot } \\
\text { Length }(\mathrm{cm})\end{array}$ & $\begin{array}{l}\text { Root Length } \\
(\mathrm{cm})\end{array}$ & $\begin{array}{l}\text { Fresh weight } \\
\text { of Shoot (mg) }\end{array}$ & $\begin{array}{l}\text { Fresh weight of } \\
\text { Root (mg) }\end{array}$ & No. of Root Galls & $\begin{array}{c}\text { Population of } \\
\text { eggs }\end{array}$ & $\begin{array}{c}\text { No. of } \\
\text { Females }\end{array}$ & $\begin{array}{c}\text { No. of } \\
\text { Juveniles }\end{array}$ \\
\hline $\mathrm{T}_{1}$ & 15.9 & 3.1 & 0.297 & 0.150 & 17.3 & 761.7 & 21.5 & 17.3 \\
\hline $\mathrm{T}_{2}$ & 18.5 & 4.5 & 0.354 & 0.182 & 11.7 & 720.7 & 16.5 & 13.7 \\
\hline $\mathrm{T}_{3}$ & 16.9 & 3.6 & 0.312 & 0.161 & 16.0 & 742.7 & 20.5 & 16.7 \\
\hline $\mathrm{T}_{4}$ & 17.5 & 3.9 & 0.337 & 0.173 & 12.0 & 732.0 & 17.1 & 14.3 \\
\hline $\mathrm{T}_{5}$ & 18.9 & 5.6 & 0.398 & 0.193 & 11.0 & 709.3 & 14.9 & 13.3 \\
\hline $\mathrm{T}_{6}$ & 19.6 & 6.3 & 0.412 & 0.227 & 10.7 & 692.3 & 14.3 & 10.7 \\
\hline $\mathrm{T}_{7}$ & 20.2 & 6.9 & 0.487 & 0.233 & 10.0 & 672.7 & 12.4 & 8.3 \\
\hline $\mathrm{T}_{8}$ & 24.0 & 9.9 & 0.777 & 0.276 & 8.0 & 562.3 & 7.1 & 3.7 \\
\hline $\mathrm{T}_{9}$ & 21.7 & 7.5 & 0.510 & 0.262 & 9.7 & 650.3 & 10.9 & 7.3 \\
\hline $\mathrm{T}_{10}$ & 27.8 & 12.8 & 1.26 & 0.356 & 3.0 & 422.7 & 6.3 & 2.7 \\
\hline $\mathrm{T}_{11}$ & 22.7 & 8.6 & 0.585 & 0.269 & 8.7 & 595.3 & 8.4 & 5.7 \\
\hline $\mathrm{T}_{12}$ & 29.4 & 14.0 & 2.267 & 0.448 & 2.0 & 348.7 & 3.6 & 1.7 \\
\hline $\mathrm{T}_{0 \text { (Control) }}$ & 10.23 & 1.86 & 0.115 & 0.110 & 39 & 964 & 25.1 & 25.66 \\
\hline $\mathrm{CV}$ & 5.79 & 10.92 & 9.61 & 8.05 & 14.10 & 10.35 & 8.51 & 19.53 \\
\hline
\end{tabular}


The number of juvenile's treatment varied between 1.7 and 25.66 among the treatment fewest juveniles were recorded $\mathrm{T}_{12}(1.7), \mathrm{T}_{10}$ (2.7) and $\mathrm{T}_{9}$ (3.7) compared with in $\mathrm{T}_{0}$ (25.66), $\mathrm{T}_{1}$ (17.3) and $\mathrm{T}_{3}$ (16.7). Significantly more galls (25.66) were recorded in the untreated control $\left(\mathrm{T}_{0}\right)$ than in all other treatment.

The present investigation on the integration of four components viz., a bio -control agent (Nematoctonus robustus), an organic amendment (Neem cake, F.Y.M. and Vermi compost) for the management of Meloidogyne graminicola in rice pot experiment revealed that all the four were compatible with each other in reducing the root galls, eggs population, females and juveniles and enhancing rice shoot and root length, fresh weight of shoot and root weight.

The combination treatments were more effective than individual treatment perhaps due to the additive effect of the bio-control agent and organic amendment. Biological control agents of soil born pathogen when applied to soils in combination with organic materials reduced nematode occurrence (Rodriguezkabang et al., 1987; Mittal et al., 1995; Chen et al., 2000; Youssef et al., 2008).

Use of organic amendments along with nematicides proved to be effective for managing H. oryzae in rice (Prasad et al., 1986). Combination of chitin amendments, neem cake and $P$. fluorescens was effective in reducing $H$. oryzae population both in soil and root (Swarna kumara et al., 1999).

Akhtar and Mahmood (1996) found a significant reduction of plant parasite and increase of predatory and free-living nematodes after application of all tested materials after an application of different rates of oilcakes of Neem (Azadirachta indica) and castor (Ricinus commnunis), composted manure and urea, as well as using of composted manure combined with Tagetes erecta. Mishra (1996) states that the Neem formulations are most effective control of root knot nematode Meloidogyne spp. as compared to other botanicals found to be most effective in reducing egg masses of the nematode on rice plant. Fertinemakil a pesticide combination of neem cake and a fungicide was found to be effective in reducing nematode population and increasing root length on wheat (Khan et al., 2007).

Nematoctonus robustus with Neemcake (29.4 $\mathrm{cm})$ significantly increased shoot length, (14.0 $\mathrm{cm})$ root length, $(2.267 \mathrm{~cm})$ fresh weight of shoot, (0.448 gm) fresh weight of root, and reducing of $(2.0 \mathrm{gm})$ root galls, (348.7) population of eggs mass, (3.6) population of females and (1.7) population of juveniles as a compared with untreated control $\left(\mathrm{T}_{0}\right)$.

\section{Acknowledgement}

Dalel Singh is highly grateful to UGC, for financial assistance through Rajiv Gandhi National Fellowship In addition to it, the author is also grateful to Dr. R. K. Singh for their valuable guidance while carrying the experiments.

\section{References}

Sharma, P., K, H., Singh, K., and L, Jagan., Indian Journal of Nematology, 2010, 40 (2): 247249.

Jaiswal, R. K., and Singh, K. P., A technique for studying the life cycle of in rice roots. International Rice Res. Notes. Meloidogyne graminicola, 2010, 35: 01174185

Bridge, J. L., Michel and Plowright R. A., Nematode parasites of rice. In: Plant parasitic nematodes in subtropical and tropical agriculture. Eds. M. Lue, R.A Sikora and J. Bridge, UK, CAB International, 1990, 69-108.

Akhtar, M., and Malik. A., Roles of organic soil amendments and soil organisms in the biological control of plant-parasitic nematodes, a review. Bio resource Technol, 2000, 74: 35-47.

Prot, J.C., and D. M. Matias., Effect of water regime on the distribution of Meloidogyne 
graminicola and other root parasitic nematodes in a rice field top sequence and pathogenicity of $M$. graminicola on rice cultivar UPLR 15. Nematologica.1995, 41: 219-228.

Soriano, I.R.S., J.C. Prot., and D.M. Matias., Expression of tolerance of Meloidogyne graminicola in rice cultivars as affected by soil type and flooding. Journal of Nematology.2000, 32: 309-317.

Musabyimana, T., and Saxena, R.C., Efficacy of neem seed derivatives against nematodes affecting banana. Phytoparasitica. 1999, 27: 43-49.

Molden, D., Water for nutrients, water for life: a comprehensive assessment of water Management in agriculture. International Water Management Institute, London. 2007.

Yadav, G., Gill, E. Humphreys., S.S. Kukul., and U.S. Walia., Effect of water management on dry seeded and puddle transplanted rice. Part 1. Crop performance. Field Crops Research. 2010, 120: 112-122.

Jain, R.K., Mathur, K.N., and Singh, R.V., Indian Journal of Nematology2007, 37: 219-221.

Dabur, K.R., and Jain, R.K., Indian Journal of Nematology 2005, 35: 81-82.

Akhtar, m., mahmood, I., Control of plantparasitic nematodes with organic and inorganic amendments in agricultural soil. Appl. Soil Ecol, 1996, 4: 243 - 247. doi: 10.1016/S0929-1393(96)00114-X

Mishra S.D., Effects of an aqueous extracts of green leaves of neem, madar and tulsi on the hatching of eggs of root-knot nematode. Meloidogyne incognita. Current Nematlology.1996, 7(2): 133-135.

Khan, A., M. S. Solangi., B. Nawab. M. Sayed and Mudassirud, Din, Efficacy of Fertinemakil and carbofuran against nematode population and growth and yield parameters of two Wheat varieties. Int. J. Biol. Biotechnol, 2007, 4:237240.

Wachira, P.M., J.W. Kimenju., S.A. Okoth., And R.K. Mibey., Stimulation of nematode destroying fungi by organic amendments applied in management of plant parasitic nematode. Asian Journal of Plant Sci., 2009, 8: 153-159.

Prasad, J. S., Panwar, M. S., and Rao, Y. S., Effect of seed-soaking with chemicals on the parasitic nematodes of rice. Indian Journal of Nematology, 1986, 16 (1), 119-121.

Swarnakumari, N., Lakshmanan, P. L., and Samiyappan, R., Screening of different isolates of Pseudomonas fluorescens against rice-root nematode, Hirschmanniella oryzae. In International seminar on integrated pest management, Hyderabad, India, 1999, (Vol. 102).

Mittal N., Saxena G., and Mukerj I., Integrated control of root knot disease in the crop plants using chitin and Paecilomyces lilacinus. Crop Protect, 1995, 14 (8): 647651.

Chen J., Abowi G.S., and Zuckerman, B.M., Efficacy of Bacillus thuringiensis, Paecilomyces marquandi, and Strptomyces costaricanus with and without organic amendments against Meloidogyne hapla infecting lettuce. J. Nematol., 2000, 32 (1): $70-77$

Rodriguez-Kabana R., Morgan-Jones G., and Chen, I., Biological control of nematodes. Soil amendments and microbial antagonists. Plant Soil, 1987, 100 (1-3): 137-147.

Youssef, M.M.A., El-Nagdi, W.M.A., and Abd El-Fattah, A.I., Efficacy of chicken compost, Bacillus thuringiensis and Pseudomonas fluorescens for bio controlling Meloidogyne incognita infecting sugar beet. Int. J. Nematol., 2008, 18 (1): $35-40$.

\section{How to cite this article:}

Dalel Singh, Sumit Kumar Pandey and Singh, R.K. 2017. Efficacy of Nematoctonus robustus along with Organic Amendment for the Management of Rice Root Knot Nematode Meloidogyne graminicola. Int.J.Curr.Microbiol.App.Sci. 6(7): 255-260. doi: https://doi.org/10.20546/ijcmas.2017.607.030 